\title{
Controlled RNA contamination and degradation and its impact on qPCR gene expression in S. epidermidis biofilms
}

\author{
Virginia Carvalhais ${ }^{a}$, Maria Delgado-Rastrollo ${ }^{\mathrm{a}, \mathrm{b}}$, Luís D.R. Melo ${ }^{\mathrm{a}}$, Nuno Cerca ${ }^{\mathrm{a}, *}$ \\ a IBB - Institute for Biotechnology and Bioengineering, Centre of Biological Engineering, University of Minho, Braga, Portugal \\ b Departamento de Ciencias Biomédicas, Área de Microbiología, Facultad de Medicina, Universidad de Extremadura, Badajoz, Spain
}

\section{A R T I C L E I N F O}

Article history:

Received 21 February 2013

Received in revised form 14 August 2013

Accepted 14 August 2013

Available online 30 August 2013

\section{Keywords:}

S. epidermidis biofilm

RNA quality

qPCR

Impurities

Temperature degradation

\begin{abstract}
A B S T R A C T
RNA quality is of utmost importance to perform gene expression quantification by qPCR. The classical methods used to determine RNA quality are based on electrophoresis and spectrophotometer assessment, namely $A_{260} / A_{280}$ and $A_{260} / A_{230}$ ratios. It was previously shown that due to the complex nature of Staphylococcus epidermidis biofilms, RNA extraction procedures could impact mRNA quality and thus accurate quantification. Herein, we contaminated and degraded RNA extracted from S. epidermidis biofilms, and assessed the effect on gene expression by qPCR. As expected, thermal degradation of RNA had a significant impact on gene expression on two out of the three tested genes. On the other hand, the contamination of the extracted RNA yielded an interesting result: while most contaminants did not changed the purity indicators or the integrity of RNA, significant changes on gene expression levels were found. This work confirms that poor RNA extraction has an important impact in qPCR quantification, emphasizing the consequences of carry-over contaminants on gene expression studies. Additionally, our results show that the parameters commonly used to assess the quality of extracted RNA from bacterial cultures seem to be insufficient to ensure reliable gene expression determination.
\end{abstract}

(c) 2013 Elsevier B.V. All rights reserved.

\section{Introduction}

Staphylococcus epidermidis is one of the most prevalent species among hospitalized patients due to its ability to form strongly adherent biofilms in indwelling medical devices (Otto, 2012; Vuong and Otto, 2002; Ziebuhr et al., 2006). Transcriptional measurements are being extensively used to study $S$. epidermidis virulence, including biofilm formation, antibiotic resistance and also intrinsic variability between isolates (Batzilla et al., 2006; Dai et al., 2012; Fluckiger et al., 2005; Handke et al., 2004). It is well known that RNA must have high quality for downstream applications like reverse-transcriptase-quantitative PCR (qPCR), the most used technique to compare relative levels of messenger RNA (mRNA) between biological samples (Nolan et al., 2006). After extraction from bacterial cells, RNA quality including purity, integrity, and yield must be assessed (Fleige and Pfaffl, 2006). According to MIQE guidelines, RNA template should be pure, show high integrity and have sufficient quantity (Bustin et al., 2009). Even concentration is important because Sieber et al. (2010) demonstrated that when a low concentration of RNA is used, a high level of variability in gene expression is obtained.

In order to evaluate purity and concentration, ultraviolet spectroscopy data is frequently obtained. With this information, absorbance ratios $260 / 280\left(A_{260} / A_{280}\right)$ and $260 / 230\left(A_{260} / A_{230}\right)$ can be

\footnotetext{
* Corresponding author at: IBB - Institute for Biotechnology and Bioengineering, Centre of Biological Engineering, University of Minho, Campus de Gualtar, 4710-057 Braga, Portugal.

E-mail address: nunocerca@ceb.uminho.pt (N. Cerca).
}

calculated (Manchester, 1996). To evaluate RNA integrity, the ribosomal RNA (rRNA) pattern should be analyzed by electrophoresis. Intact RNA in prokaryotic cells should present sharp bands without smearing, and the 23S rRNA should present twice the intensity of the 16S rRNA band (Pinto et al., 2009; Sambrook and Russel, 2001). However, in the last few years, a methodology based on a microfluidic capillary electrophoresis system has been increasingly used to quantify and determine RNA integrity, such as 2100 Bioanalyzer (Agilent Technologies) and Experion (Bio-Rad) (Riedmaier et al., 2010). Nevertheless, the combination of agarose gel electrophoresis and NanoDrop ${ }^{\mathrm{TM}}$ spectrophotometer is still used most of the time due to simplicity and cost-effective balance (Jahn et al., 2008). Furthermore, RNA Integrity Number (RIN) and RNA quality number (RQI) thresholds for high quality prokaryotic total RNA weren't defined yet, however, a RIN above 7 has been accepted as appropriate for qPCR (Jahn et al., 2008).

As demonstrated by some studies, different RNA extraction methods can yield RNA with distinct quality, and this has been associated with the complex nature of biological samples (Atshan et al., 2012; Franca et al., 2011, 2012a; Pinto et al., 2009). Moreover, different components from biological samples (Radstrom et al., 2004; Tichopad et al., 2004) or from the RNA isolation procedure used, such as ethanol, isopropanol, phenol and many salts can inhibit the PCR process (Bar et al., 2012; Radstrom et al., 2004; Wilson, 1997). In addition, temperature is also a known factor which interferes with the preservation of RNA integrity (Opitz et al., 2010; Sung et al., 2003).

Franca et al. (2012a) have recently shown that mRNA quantification in bacterial biofilms was highly variable depending on the RNA 
extraction kit used, and RNA quality indicators did not always correlate with a reliable gene expression quantification. This is of significant importance since the most used quality indicators that should guarantee RNA quality seem not to be enough to determine the reliability of bacterial gene expression (Lloyd et al., 2010). In this study, we aimed to assess how induced RNA degradation, by temperature and controlled contamination of RNA, affected quality parameters and their consequences in gene expression of S. epidermidis biofilms.

\section{Material and methods}

\subsection{Biofilm growth conditions}

Biofilm forming S. epidermidis 9142 was used as a model strain. One colony was inoculated in Tryptic Soy Broth (TSB) (Oxoid) and incubated at $37{ }^{\circ} \mathrm{C}$ in a shaker at $120 \mathrm{rpm}$ overnight. Then, a 1:100 dilution was performed in TSB enriched with $0.4 \%(\mathrm{w} / \mathrm{v})$ glucose (Fisher Scientific) in a 24-well plate and was incubated in the same conditions. After $24 \mathrm{~h}$, biofilms were washed with phosphate buffer solution (PBS) diluted 1:3 (180 mM NaCl, $3 \mathrm{mM} \mathrm{KCl}, 9 \mathrm{mM} \mathrm{Na}_{2} \mathrm{HPO}_{4} \cdot 2 \mathrm{H}_{2} \mathrm{O}, 1.5 \mathrm{mM}$ $\mathrm{KH}_{2} \mathrm{PO}_{4}$ ) and suspended in $1 \mathrm{~mL}$ of PBS, followed by centrifugation at $16000 \times g$ for $10 \mathrm{~min}$ at $4{ }^{\circ} \mathrm{C}$.

\subsection{RNA extraction}

Total RNA from S. epidermidis biofilm was extracted as described before (Franca et al., 2012b). In brief, this protocol conjugates mechanical and chemical lyses (glass beads, phenol) with RNA isolation column systems (E.Z.N.A. ${ }^{\circledR}$ Total RNA Kit I). RNA was diluted in DNase/RNAse-free water and digested with DNAse I (1 U) (Fermentas) following the manufacturer's instructions. RNA extraction was performed several times, and samples were pooled and stored at $-80{ }^{\circ} \mathrm{C}$.

\subsection{Controlled RNA degradation and contamination}

RNA aliquots of $30 \mu \mathrm{L}$ (100 ng) were used for temperature degradation and controlled contamination tests. Clean RNA aliquots were submitted to different temperature treatments for different incubation times: $95{ }^{\circ} \mathrm{C}, 65^{\circ} \mathrm{C}$ or room temperature (RT) for 10 and $60 \mathrm{~min}$. This incubation was performed in a thermocycler to avoid evaporation. Impurities were added to each RNA aliquot. The impurities selected for this study were either involved in the RNA extraction process or from the biological samples itself. To each independent RNA aliquot, 1 or $6 \mu \mathrm{L}$ of Wash buffer II (WBII) (E.Z.N.A. ${ }^{\circledR}$ Total RNA Kit I), 1 or $6 \mu \mathrm{L}$ of S. epidermidis biofilm matrix (rich in polysaccharides, proteins, extracellular DNA and teichoic acids (Flemming and Wingender, 2010)), or $1 \mu \mathrm{L}$ of $90 \%$ phenol solution (AppliChem) (used in organic extraction) were added. S. epidermidis biofilm matrix protein and polysaccharide contents were determined as described previously (Franca et al., 2011). Protein and polysaccharide contents were $0.31 \mathrm{mg} / \mathrm{mL}$ and $0.11 \mathrm{mg} / \mathrm{mL}$, respectively.

\subsection{RNA quality and quantity assessment}

The concentration and purity of the RNA aliquots was spectrometrically assessed using a NanoDrop $1000^{\mathrm{TM}}$ (Thermo Scientific), following the manufacturer's instructions. The $A_{260} / A_{280}$ ratio was used as indicator of protein contamination and $A_{260} / A_{230}$ ratio as indicator of polysaccharide, phenol, and/or chaotropic salts contamination (Tavares et al., 2011). The integrity of the total RNA was assessed by visualization of the 23S/16S rRNA band pattern in a $1 \%$ agarose gel. Non-denaturing electrophoresis was carried-out at $80 \mathrm{~V}$ for $60 \mathrm{~min}$. The gel was stained with Midori Green DNA staining (GRiSP) in TAE buffer (Tris-acetate-EDTA) and visualized using ChemiDoc ${ }^{\mathrm{TM}} \mathrm{XRS}^{+}$(Bio-Rad).

\section{5. $c D N A$ synthesis and $q P C R$}

To determine if the RNA aliquots were functional, $600 \mathrm{ng}$ of total RNA was reverse transcribed using RevertAid First strand cDNA synthesis (Fermentas) using the specific priming strategy and following the manufacturer's instructions (Invitrogen). Primers for icaA, $p s m \beta$, pgi and 16S rRNA genes were designed with Primer3 software (Rozen and Skaletsky, 2000) (Table 1). The selected genes are transcribed from different regions of the bacterial chromosome. PCR amplification efficiency was tested and relative quantification normalized to control was determined by a variation of Livak method, $\mathrm{E}^{\left(\mathrm{C}_{\mathrm{T}} \text { reference gene }-\mathrm{C}_{\mathrm{T}} \text { target gene) }\right.}$ (Livak and Schmittgen, 2001). qPCR was performed to quantify the mRNA transcripts. The experiment was performed using iQ SYBR $2 \times$ green supermix (Bio-Rad) and CFX96 ${ }^{\mathrm{TM}}$ thermocycler (Bio-Rad) with the following cycling parameters: $30 \mathrm{~s}$ at $94{ }^{\circ} \mathrm{C}$ followed by 40 repeats of $5 \mathrm{~s}$ at $94^{\circ} \mathrm{C}, 10 \mathrm{~s}$ at $60^{\circ} \mathrm{C}$, and finally $15 \mathrm{~s}$ at $72{ }^{\circ} \mathrm{C}$. To ensure the absence of genomic DNA contamination, a negative control was included in the reverse transcriptase reaction. Genomic DNA contamination was not considered significant when the cycle threshold difference between the no-reverse transcriptase and the respective sample was above 15 cycles. The cycle threshold detection of each gene was determined using the standard parameters of the software. The melting curves were evaluated to ensure the absence of unspecific products and primer dimer formation. For each condition, at least three aliquots were used.

\subsection{Statistical analysis}

Statistical analysis was performed with GraphPad Prism ${ }^{\circledR}$ Software version 5 (GraphPad, CA, US) using unpaired $t$-test to compare control with treated RNA aliquots. A $p$ value less than 0.05 was considered statistically significant.

\section{Results and discussion}

\subsection{RNA degradation}

It is widely accepted that RNA with high purity and integrity is of extreme importance to guarantee a reliable analysis of gene expression (Vermeulen et al., 2011). However, it has also been shown that bacterial gene expression variability does not always correlate with high quality RNA, as determined by the standard parameters of RNA quality (Franca et al., 2012a). Based on the analysis of agarose gel electrophoresis and NanoDrop measurement, we assessed the impact of RNA quality on qPCR gene expression using $S$. epidermidis biofilms. For that, we performed two independent experiments, namely, degrading RNA by thermal treatment or contaminating RNA with impurities from the extraction process or from the biological sample.

From one pool of intact RNA extracted from independent biofilms, we used different aliquots that were subjected to distinct treatments. To assess degradation by temperature, different RNA aliquots were treated for 10 or $60 \mathrm{~min}$ at room temperature, 65 or $95^{\circ} \mathrm{C}$. Based on the established criteria for RNA integrity, as can be seen in Fig. 1, RNA

Table 1

Primers used in cDNA synthesis and qPCR amplification.

\begin{tabular}{llll}
\hline $\begin{array}{l}\text { Target } \\
\text { gene }\end{array}$ & Primer sequence $\left(5^{\prime}\right.$ to $\left.3^{\prime}\right)$ & $\begin{array}{l}\text { Melting temperature } \\
\left({ }^{\circ} \mathrm{C}\right)\end{array}$ & $\begin{array}{l}\text { Amplicon } \\
\text { size }(\mathrm{bp})\end{array}$ \\
\hline$i c a A$ & $\begin{array}{l}\text { FW TGCACTCAATGAGGGAATCA } \\
\text { RV TAACTGCGCCTAATTTGGATT }\end{array}$ & 60 & 134 \\
\multirow{2}{*}{ p $i$} & $\begin{array}{l}\text { FW TACTACGACAGAACCAGCAG } \\
\text { RV CATCAGGTACAACAAACGTC }\end{array}$ & 59 & 170 \\
$p s m \beta$ & $\begin{array}{l}\text { FW TTGCAAATACAGTAAAAGCAGCA } \\
\text { RV TCCGAAGATTTACCTAATACGC }\end{array}$ & 59 & 107 \\
$16 \mathrm{~S}$ rRNA & $\begin{array}{l}\text { FW GGGCTACACACGTGCTACAA } \\
\text { RV GTACAAGACCCGGGAACGTA }\end{array}$ & 60 & 176 \\
\hline
\end{tabular}




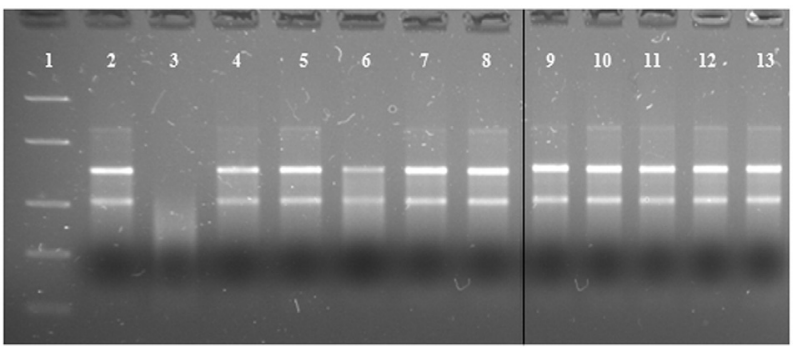

Fig. 1. Visualization of $16 \mathrm{~S} / 23 \mathrm{~S}$ rRNA bands in $1 \%$ agarose gel electrophoresis containing RNA aliquots submitted to different temperatures and incubation, and RNA aliquots with impurities. 1-FastRuler Middle Range DNA Ladder (Fermentas); 2-Control; 3-95 ${ }^{\circ} \mathrm{C}, 60 \mathrm{~min}$; $4-65{ }^{\circ} \mathrm{C}, 60 \mathrm{~min}$; 5-room temperature, $60 \mathrm{~min} ; 6-95{ }^{\circ} \mathrm{C}, 10 \mathrm{~min}$; 7-65 ${ }^{\circ} \mathrm{C}, 10 \mathrm{~min}$; $8-\mathrm{RT}, 10 \mathrm{~min}$; $9-1 \mu \mathrm{L}$ of $\mathrm{S}$. epidermidis biofilm matrix; $10-6 \mu \mathrm{L}$ of $S$. epidermidis biofilm matrix; $11-1 \mu \mathrm{L}$ of WBII; $12-6 \mu \mathrm{L}$ of WBII; $13-1 \mu \mathrm{L}$ of $90 \%$ phenol.

submitted to $95{ }^{\circ} \mathrm{C}$ showed significant degradation at $60 \mathrm{~min}$ and less degradation at $10 \mathrm{~min}$ of incubation. At lower temperatures, no RNA degradation was detected by agarose gel electrophoresis. As expected, thermal degradation did not decrease, per se, the purity of RNA samples
(Fig. 2A). However, it is important to stress that agarose gel electrophoresis lacks sensitivity (Bustin and Nolan, 2004; Denisov et al., 2008) and therefore we cannot exclude that RNA was somewhat damaged in the $65{ }^{\circ} \mathrm{C}$ treatment.

\subsection{RNA contamination}

Established criteria for the RNA quality specify that RNA stability can be affected by internal (enzymes, toxins) and exogenous factors (heat, chemical buffers, radiation), and consequently interfere with gene expression studies (Fleige and Pfaffl, 2006). Taking this into consideration, intentional RNA contamination was performed using WBII, S. epidermidis biofilm matrix or phenol. As can be seen in the agarose gel from RNA aliquots contaminated with specific impurities (Fig. 1), RNA didn't show any visible degradation. On the other hand, phenol significantly decreased both $A_{260} / A_{280}$ and $A_{260} / A_{230}$ absorbance ratios (Fig. 2B). These should be greater than 1.8 revealing a low level of protein contamination and, low level of polysaccharides, phenol, alcohol and other contaminants, respectively. Interestingly, RNA contaminated with $6 \mu \mathrm{L}$ of $S$. epidermidis biofilm matrix decreased $A_{260} / A_{230}$ ratio but not $A_{260} / A_{280}$ ratio, indicating that the protein content of the matrix was not sufficient to interfere in the UV spectrophotometric measurements.
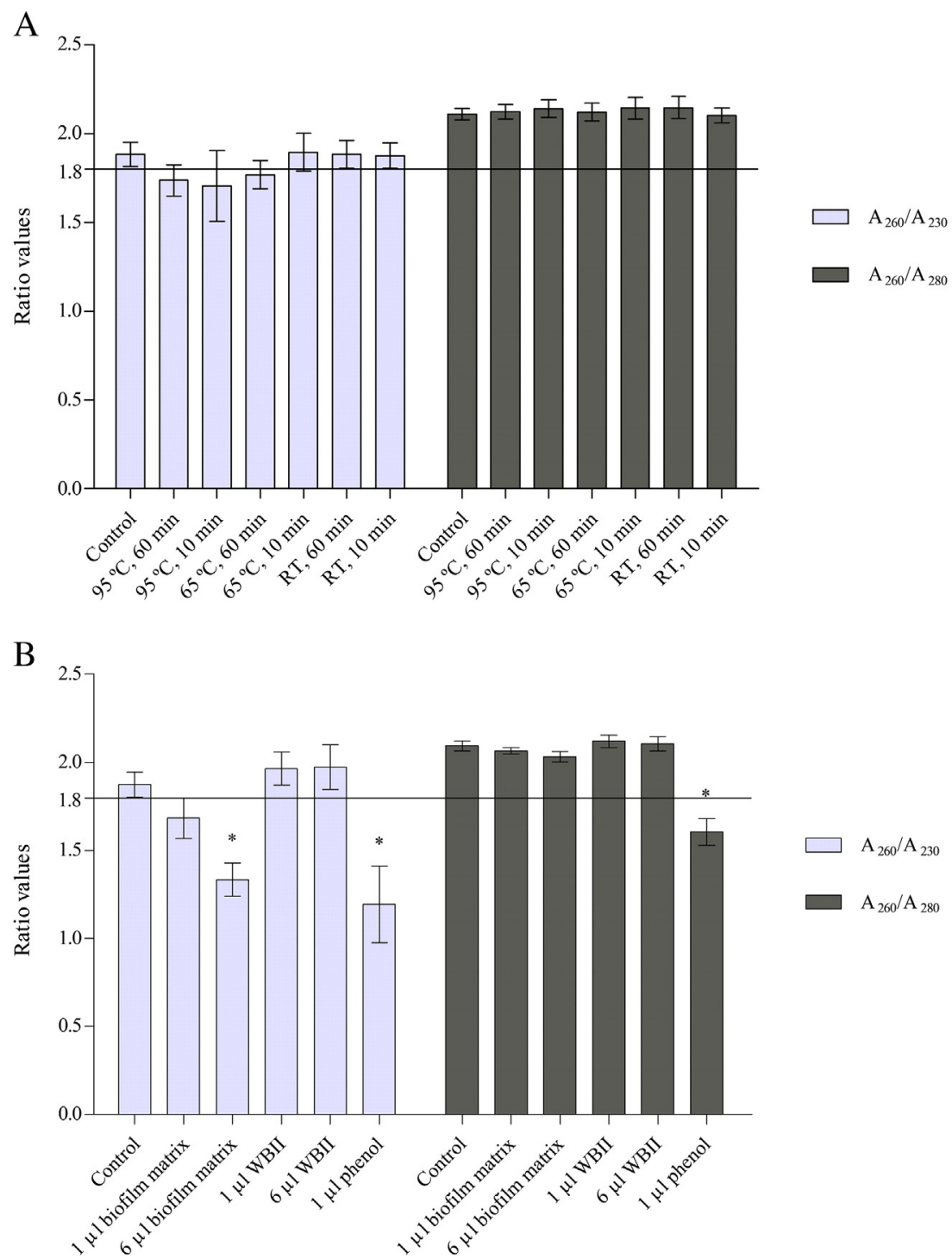

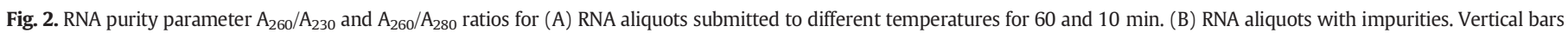
denote standard error of the mean, while * indicates statistically significant differences with unpaired $t$-test for a $p<0.05$. 
There are some sources of known contaminants which produce peaks in the $220-230 \mathrm{~nm}$ region such as chaotropic salts, like guanidinium isothiocyanate, and phenol (Chomczynski and Sacchi, 1987). Other reagents used in RNA isolation can absorb near $270 \mathrm{~nm}$ wavelength, resulting in an over estimation of nucleic acid concentration. Phenol is an example of organic substance with acidic properties which can absorb near 260 nm (Hazardous Substances Data Bank). This can explain why RNA contaminated with $1 \mu \mathrm{L}$ of phenol lead to significant differences in quality ratios, although loss of RNA integrity wasn't observed (Fig. 1). The $A_{260} / A_{230}$ ratio under 1.8 was also found in RNA with phenol, an indication of phenolic contamination.

\subsection{Gene expression}

After determining the effect of degradation by temperature and controlled RNA contamination using common RNA quality indicators, we performed qPCR of each sample in order to determine the real effect of the RNA treatments on specific S. epidermidis gene transcripts, as well as to confirm if the RNA quality indicators were predictive of gene expression stability and reproducibility. qPCR was done to measure gene expression of three $S$. epidermidis genes, namely icaA (involved in biofilm formation (Rohde et al., 2007)), psm $\beta$ (implicated in biofilm modulation (Yao et al., 2005)) and pgi gene (involved in glycolysis (Gill et al., 2005)). Efficiency of primers in aliquots was analyzed to confirm that efficiency was not altered by temperature neither by addition of impurities.

When RNA was submitted to different temperatures, only incubation at $95{ }^{\circ} \mathrm{C}$ (in both time points) showed statistically significant differences in the expression of $i c a A$ and pgi genes (Fig. 3). Interestingly, psm $\beta$ expression wasn't significantly affected by temperature treatment. This can be explained by Opitz et al.'s study which address that not all eukaryotic gene expression was affected by temperature degradation (Opitz et al., 2010). It is important to remember that RNA aliquots which were subjected to $95{ }^{\circ} \mathrm{C}$ for $60 \mathrm{~min}$, showed loss of integrity but less visible degradation was seen for RNA aliquots incubated at $95{ }^{\circ} \mathrm{C}$ for $10 \mathrm{~min}$ (Fig. 1). Schoor et al. (2003) support that partially degraded RNA samples with visible ribosomal bands can have gene expression profiles similar to intact RNA and lead to meaningful results if used carefully, although it is widely known that RNA integrity affects performance of qPCR and consequently the gene expression profile (Becker et al., 2010). Despite the effect of thermal degradation on RNA integrity, NanoDrop quality ratios didn't change, indicating that gene expression differences could have been anticipated by agarose gel electrophoresis but not by spectrophotometric measurement.

Contrary to thermal degradation, some of the added impurities reduced the RNA purity indicators, but not RNA integrity (Fig. 1). Interestingly, we detected significant differences in the expression of the three tested genes (Fig. 4), supporting that RNA integrity is not sufficient to determine a reliable gene expression. This shows that even intact RNA, assessed with traditional methods, doesn't guarantee that gene expression results won't be affected since RNA samples might contain inhibitors which can interfere with PCR efficiency (Bustin and Nolan, 2004; Wong and Medrano, 2005). It is assumed that the effect of inhibitors over qPCR can vary between assays and can be minimized using a reference gene amplified at the same time as the target gene (Nolan and Bustin, 2008). One of the methods to assess PCR efficiency is to do a serial dilution of the sample in which absence of inhibitors doesn't affect relative fold increase in diluted cDNA (Stahlberg et al., 2003).

In the biofilm matrix, the only contaminant originated from the biological sample, influenced gene expression in lower extent (up to 3.5 fold) compared to contaminants originated from the RNA extraction process. Phenol was the contaminant with the most pronounced effect, resulting in gene expression differences as great as 230 -fold.

\section{Conclusions}

As expected, RNA that showed loss of integrity had different genetic expression in some genes. However, despite no visible loss of rRNA integrity and no statistically significant alterations in NanoDrop parameters, contamination with WBII also strongly influenced gene expression.

This work suggests that while the electrophoresis band pattern analysis and NanoDrop quality parameters can reveal physical characteristics of RNA, they are not enough to determine the reliability and stability of gene expression determinations.

While it's common practice to use the same RNA extraction process and/or kit in order to reduce variability of gene expression, such approaches will potentially mask possible structural carry-over contaminants that are not detected by common quality indicators, but nevertheless influence gene expression. The development of more robust PCR kits, more tolerant to inhibitors, could possibly prevent the reported significant changes in gene expression. Contrary to common practice, this work suggests that the usage of two independent and distinct RNA extraction methods in each experiment will allow a more robust gene expression determination, considering that if both methods yield

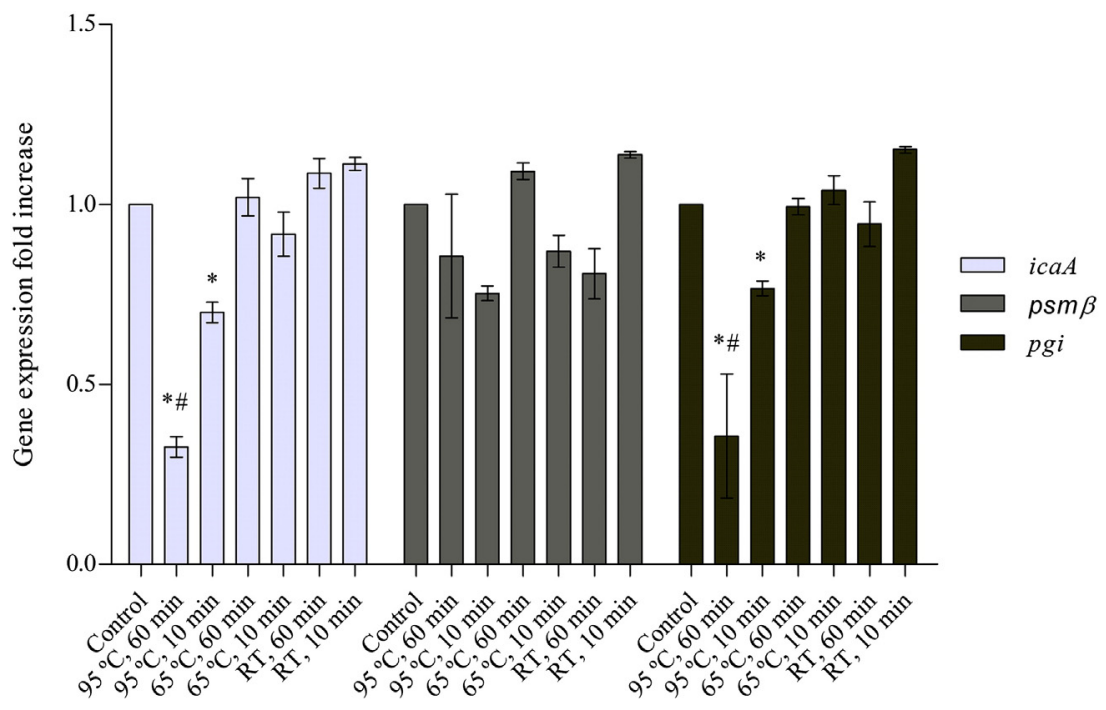

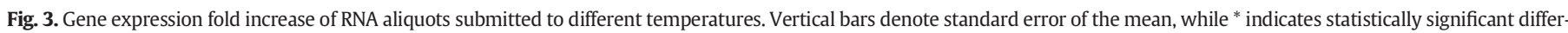
ences with unpaired $t$-test for a $p<0.05$ and ${ }^{\#}$ indicates lost of integrity. 


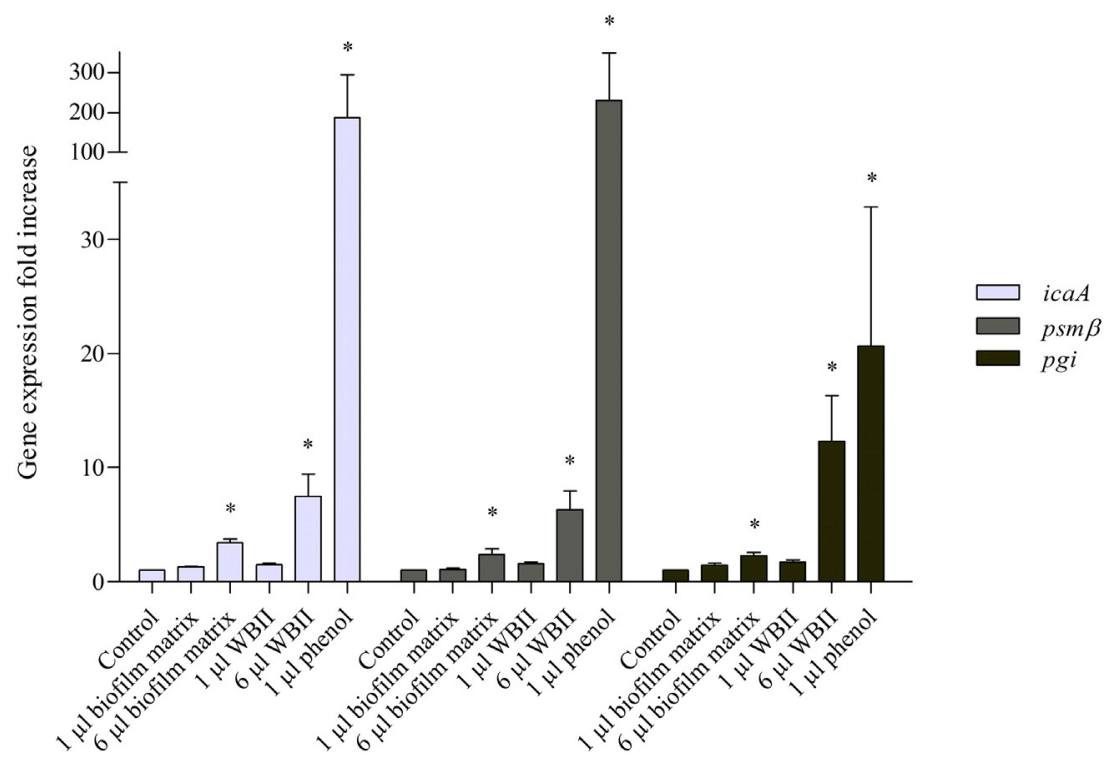

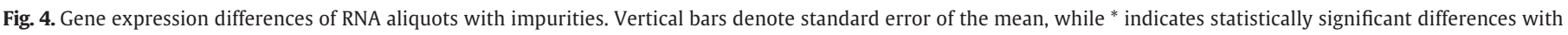
unpaired $t$-test for a $p<0.05$.

the same final result, the chances of structural carry-over contaminants interfering with gene expression studies will be reduced.

\section{Acknowledgments}

This work was funded by the Fundacão para a Ciência e a Tecnologia (FCT) and COMPETE grants PTDC/BIA-MIC/113450/2009 and FCOMP01-0124-FEDER-014309. The following authors had an individual FCT fellowship: VC (SFRH/BD/78235/2011); LDRM (SFRH/BD/66166/2009).

\section{References}

Atshan, S.S., Shamsudin, M.N., Lung, L.T., Ling, K.H., Sekawi, Z., Pei, C.P., Ghaznavi-Rad, E. 2012. Improved method for the isolation of RNA from bacteria refractory to disruption, including S. aureus producing biofilm. Gene 494, 219-224.

Bar, T., Kubista, M., Tichopad, A., 2012. Validation of kinetics similarity in qPCR. Nucleic Acids Res. 40, 1395-1406.

Batzilla, C.F., Rachid, S., Engelmann, S., Hecker, M., Hacker, J., Ziebuhr, W., 2006. Impact of the accessory gene regulatory system (Agr) on extracellular proteins, codY expression and amino acid metabolism in Staphylococcus epidermidis. Proteomics 6 , 3602-3613.

Becker, C., Hammerle-Fickinger, A., Riedmaier, I., Pfaffl, M.W., 2010. mRNA and microRNA quality control for RT-qPCR analysis. Methods 50, 237-243.

Bustin, S.A., Nolan, T., 2004. Pitfalls of quantitative real-time reverse-transcription polymerase chain reaction. J. Biomol. Tech. 15, 155-166.

Bustin, S.A., Benes, V., Garson, J.A., Hellemans, J., Huggett, J., Kubista, M., Mueller, R., Nolan, T., Pfaffl, M.W., Shipley, G.L., Vandesompele, J., Wittwer, C.T., 2009. The MIQE guidelines: minimum information for publication of quantitative real-time PCR experiments. Clin. Chem. 55, 611-622.

Chomczynski, P., Sacchi, N., 1987. Single-step method of RNA isolation by acid guanidinium thiocyanate-phenol-chloroform extraction. Anal. Biochem. 162, 156-159.

Dai, L., Yang, L., Parsons, C., Findlay, V.J., Molin, S., Qin, Z., 2012. Staphylococcus epidermidis recovered from indwelling catheters exhibit enhanced biofilm dispersal and "self-renewal" through downregulation of agr. BMC Microbiol. 12, 102

Denisov, V., Strong, W., Walder, M., Gingrich, F., Wintz, H., 2008. Development and validation of RQI: an RNA quality indicator for the Experion automated electrophoresis system. Bio-Rad, Bull. \#5761.

Fleige, S., Pfaffl, M.W., 2006. RNA integrity and the effect on the real-time qRT-PCR performance. Mol. Aspects Med. 27, 126-139.

Flemming, H.C., Wingender, J., 2010. The biofilm matrix. Nat. Rev. Microbiol. 8, 623-633.

Fluckiger, U., Ulrich, M., Steinhuber, A., Doring, G., Mack, D., Landmann, R., Goerke, C., Wolz C., 2005. Biofilm formation, icaADBC transcription, and polysaccharide intercellular adhesin synthesis by staphylococci in a device-related infection model. Infect. Immun. 73, 1811-1819.

Franca, A., Melo, L.D., Cerca, N., 2011. Comparison of RNA extraction methods from biofilm samples of Staphylococcus epidermidis. BMC Res. Notes. 4, 572

Franca, A., Bento, J.C., Cerca, N., 2012a. Variability of RNA quality extracted from biofilms of foodborne pathogens using different kits impacts mRNA quantification by qPCR Curr. Microbiol. 65, 54-59.
Franca, A., Freitas, A.I., Henriques, A.F., Cerca, N., 2012b. Optimizing a qPCR gene expression quantification assay for $S$. epidermidis biofilms: a comparison between commercial kits and a customized protocol. PLoS One 7, e37480.

Gill, S.R., Fouts, D.E., Archer, G.L., Mongodin, E.F., Deboy, R.T., Ravel, J., Paulsen, I.T., Kolonay, J.F., Brinkac, L., Beanan, M., Dodson, R.J., Daugherty, S.C., Madupu, R., Angiuoli, S.V., Durkin, A.S., Haft, D.H., Vamathevan, J., Khouri, H., Utterback, T., Lee, C., Dimitrov, G., Jiang, L., Qin, H., Weidman, J., Tran, K., Kang, K., Hance, I.R., Nelson, K.E., Fraser, C.M., 2005. Insights on evolution of virulence and resistance from the complete genome analysis of an early methicillin-resistant Staphylococcus aureus strain and a biofilm-producing methicillin-resistant Staphylococcus epidermidis strain. J. Bacteriol. 187, 2426-2438.

Handke, L., Conlon, K., Slater, S., Elbaruni, S., Fitzpatrick, F., Humphreys, H., Giles, W., Rupp, M., Fey, P., O'Gara, J., 2004. Genetic and phenotypic analysis of biofilm phenotypic variation in multiple Staphylococcus epidermidis isolates. J. Med. Microbiol. 53, 367-374

Jahn, C.E., Charkowski, A.O., Willis, D.K., 2008. Evaluation of isolation methods and RNA integrity for bacterial RNA quantitation. J. Microbiol. Methods 75, 318-324.

Livak, K.J., Schmittgen, T.D., 2001. Analysis of relative gene expression data using realtime quantitative PCR and the 2(-Delta Delta C(T)) Method. Methods 25, 402-408.

Lloyd, K.G., Macgregor, B.J., Teske, A., 2010. Quantitative PCR methods for RNA and DNA in marine sediments: maximizing yield while overcoming inhibition. FEMS Microbiol. Ecol. 72, 143-151.

Manchester, K.L., 1996. Use of UV methods for measurement of protein and nucleic acid concentrations. Biotechniques 20, 968-970.

Nolan, T., Bustin, S.A. 2008. Procedures for quality control of RNA samples for use in quantitative reverse transcription PCR. In: Keer, J.T., Birch, L. (Eds.), Essentials of Nucleic Acid Analysis: A Robust Approach. Royal Society of Chemistry, UK, pp. 189-207.

Nolan, T., Hands, R.E., Bustin, S.A., 2006. Quantification of mRNA using real-time RT-PCR. Nat. Protoc. 1, 1559-1582.

Opitz, L., Salinas-Riester, G., Grade, M., Jung, K., Jo, P., Emons, G., Ghadimi, B.M., Beissbarth, T., Gaedcke, J., 2010. Impact of RNA degradation on gene expression profiling. BMC Med. Genomics. 3, 36

Otto, M., 2012. Molecular basis of Staphylococcus epidermidis infections. Semin. Immunopathol. 34, 201-214.

Pinto, F.L., Thapper, A., Sontheim, W., Lindblad, P., 2009. Analysis of current and alternative phenol based RNA extraction methodologies for cyanobacteria. BMC Mol. Biol. 10,79 .

Radstrom, P., Knutsson, R., Wolffs, P., Lovenklev, M., Lofstrom, C., 2004. Pre-PCR processing: strategies to generate PCR-compatible samples. Mol. Biotechnol. $26,133-146$.

Riedmaier, I., Bergmaier, M., Pfaffl, M.W., 2010. Comparison of two available platforms for determination of RNA quality. Biotechnol. Biotechnol. Equip. 24 (4), 2154-2159.

Rohde, H., Burandt, E.C., Siemssen, N., Frommelt, L., Burdelski, C., Wurster, S., Scherpe, S., Davies, A.P., Harris, L.G., Horstkotte, M.A., Knobloch, J.K., Ragunath, C., Kaplan, J.B., Mack, D., 2007. Polysaccharide intercellular adhesin or protein factors in biofilm accumulation of Staphylococcus epidermidis and Staphylococcus aureus isolated from prosthetic hip and knee joint infections. Biomaterials 28, 1711-1720.

Rozen, S., Skaletsky, H., 2000. Primer3 on the WWW for general users and for biologist programmers. In: Krawetz, S., Misenser, S. (Eds.), Methods in Molecular Biology. Human Press, Totowa, NJ, pp. 365-386.

Sambrook, J., Russel, D.W., 2001. Molecular Cloning: A Laboratory Manual, first ed. Cold Spring Harbor Laboratory Press, New York. 
Schoor, O., Weinschenk, T., Hennenlotter, J., Corvin, S., Stenzl, A., Rammensee, H.G., Stevanovic, S., 2003. Moderate degradation does not preclude microarray analysis of small amounts of RNA. Biotechniques 35, 1192-1201.

Sieber, M.W., Recknagel, P., Glaser, F., Witte, O.W., Bauer, M., Claus, R.A., Frahm, C., 2010 Substantial performance discrepancies among commercially available kits for reverse transcription quantitative polymerase chain reaction: a systematic comparative investigator-driven approach. Anal. Biochem. 401, 303-311.

Stahlberg, A., Aman, P., Ridell, B., Mostad, P., Kubista, M., 2003. Quantitative real-time PCR method for detection of B-lymphocyte monoclonality by comparison of kappa and lambda immunoglobulin light chain expression. Clin. Chem. 49, 51-59.

Sung, K., Khan, S.A., Nawaz, M.S., Khan, A.A., 2003. A simple and efficient Triton X-100 boiling and chloroform extraction method of RNA isolation from Gram-positive and Gram-negative bacteria. FEMS Microbiol. Lett. 229, 97-101.

Tavares, L., Alves, P.M., Ferreira, R.B., Santos, C.N., 2011. Comparison of different methods for DNA-free RNA isolation from SK-N-MC neuroblastoma. BMC Res. Notes. 1, $140-145$.
Tichopad, A., Didier, A., Pfaffl, M.W., 2004. Inhibition of real-time RT-PCR quantification due to tissue-specific contaminants. Mol. Cell Probes 18, 45-50.

Vermeulen, J., De Preter, K., Lefever, S., Nuytens, J., De Vloed, F., Derveaux, S., Hellemans, J., Speleman, F., Vandesompele, J., 2011. Measurable impact of RNA quality on gene expression results from quantitative PCR. Nucleic Acids Res. 39, e63.

Vuong, C., Otto, M., 2002. Staphylococcus epidermidis infections. Microbes Infect. 4, 481-489. Wilson, I.G., 1997. Inhibition and facilitation of nucleic acid amplification. Appl. Environ. Microbiol. 63, 3741-3751.

Wong, M.L., Medrano, J.F., 2005. Real-time PCR for mRNA quantitation. Biotechniques 39, 75-85.

Yao, Y., Sturdevant, D.E., Otto, M., 2005. Genomewide analysis of gene expression in Staphylococcus epidermidis biofilms: insights into the pathophysiology of S. epidermidis biofilms and the role of phenol-soluble modulins in formation of biofilms. J. Infect. Dis. 191, 289-298.

Ziebuhr, W., Hennig S. Eckart, M. Kranzler, H., Batzilla, C. Kozitskaya, S. 2006. Nosocomial infections by Staphylococcus epidermidis: how a commensal bacterium turns into a pathogen. Int. J. Antimicrob. Agents 28 (Suppl. 1), S14-S20. 